\title{
SOME FURTHER OBSERVATIONS ON PARENTAL CONSANGUINEOUS MARRIAGES OF ANENCEPHALY IN JAPAN
}

\author{
Yoko IMAIZUMI \\ Institute of Population Problems, \\ Ministry of Health and Welfare, Tokyo, Japan
}

\begin{abstract}
Summary Parental consanguineous marriages for the 482 index patients with anencephaly were examined from the koseki. The rate of first cousin marriages among the parents of anencephalic patients is $1.87 \%$. The rates are $1.5 \%$ in urban and $3.8 \%$ in rural areas. The difference between the rates of first cousin marriages among parents of anencephalic patients and among the general population is not statistically significant. It seems that the inheritance of anencephaly is not related to a specific number of recessive genes.
\end{abstract}

Penrose (1957) concluded that recessive anencephaly exists. Multiple-affected sibs reported by several authors (McKusick, 1975) seem to support Penrose's opinion. The evidence for genetic factors being important in the aetiology of anencephaly comes from an influence of parental consanguinity (Carter, 1974). According to Stevenson et al. (1966), parental consanguinity for malformations of central nervous system was high. However, these high consanguineous marriages were especially obtained from Alexandria and Bombay. On the other hand, a rate of parental cousin marriage for the malformations in South Wales and Greater London was low, but higher than that estimated for the corresponding general population (Carter et al., 1968; Carter and Evans, 1973).

However, the present author (1976) reported that the rates of first cousin marriages among parents of anencephalic patients, 6 in 323 or $1.86 \%$, and in the general population, 200 in 9,385 or $2.13 \%$ were not significantly different. The present communication deals with further analyses of observation on such marriages including additional data obtained after the publication of the previous paper.

\section{MATERIAL}

Information for the malformations were obtained from the fetal death and death certificate records in Japan (see Imaizumi, 1974). Dates of fetal death and postnatal death for the index patients were between 1969 and 1975, mainly 1969 to 1971 . Parental consanguineous marriages for the 482 anencephalic cases were examined from the koseki, the family registration records in Japan. 
Table 1. Parental consanguineous marriages of anencephaly by year of marriage and area.

\begin{tabular}{lrrrrrrr}
\hline \multirow{2}{*}{ Type of marriage } & \multicolumn{3}{c}{ Married year } & & \multicolumn{3}{c}{ Area } \\
\cline { 2 - 5 } \cline { 7 - 8 } & -1966 & $1967-$ & Total & & Urban & Rural & Total \\
\hline Ist cousin & 3 & 6 & 9 & & 6 & 3 & 9 \\
$11 / 2$ cousin & 2 & 0 & 2 & & 2 & 0 & 2 \\
2nd cousin & 0 & 1 & 1 & & 1 & 0 & 1 \\
Half $11 / 2$ cousin & 0 & 1 & 1 & & 0 & 1 \\
Unrelated & 138 & 331 & 469 & & 393 & 76 & 469 \\
$\quad$ Total & 143 & 339 & 482 & & 403 & 79 & 482 \\
\hline Rate of first & 0.0210 & 0.0177 & 0.0187 & & 0.0149 & 0.0380 & 0.0187 \\
cousin marriage & 0.0149 &
\end{tabular}

\section{RESULTS AND DISCUSSION}

Table 1 shows the frequency of parental consanguineous marriages of anencephaly according to marriage year of the couple. Consanguineous marriages for the 323 among 482 cases were published by Imaizumi (1976). As shown in Table 1, the rate of first cousin marriages in the parents of anencephaly is 9 in 482 or $1.87 \%$. Where, the married year of the couple is divided into two groups: 1966 or before and 1967 or after. Rates of first cousin marriages of the old and young groups for anencephaly are $2.10 \%(3 / 143)$ and $1.77 \%(6 / 339)$, respectively. The rates of parental first cousin marriages of anencephaly in urban and rural areas are $1.5 \%(6 / 403)$ and $3.8 \%(3 / 79)$, respectively. The rate of first cousin marriages declines as a function of the year of marriage in Japan (Imaizumi et al., 1975). According to Imaizumi et al., the mean rate of first cousin marriages for married years during 1967 to 1972 was $0.89 \%(17 / 1911)$ in general population. The rate of first cousin marriages for most recent years is lower in the general population than in the parent of anencephalic patients $(1.77 \%)$. The difference is not statistically significant.

On the basis of the above statements, as mentioned by Imaizumi (1976), it seems that the inheritance of anencephaly is not related to a specific number of recessive genes.

Acknowledgments I wish to express hearty thanks to Mrs. Fusami Mita for her collaboration. This investigation was supported in part by a grant from the Ministry of Health and Welfare of Japan for Research on Handicapped Children, 1976.

\section{REFERENCES}

Carter, C. O. 1974. Clues to the aetiology of neural tube malformations. Dev. Med. Child. Neurol. 16: (Suppl. 32): 3-15.

Carter, C. O., David, P. A. and Laurence, K. M. 1968. A family study of major central nervous system malformations in South Wales. J. Med. Genet. 5: 81-106.

Carter, C. O. and Evans, K. 1973. Spina bifida and anencephalus in Greater London. J. Med. Genet. 10: 209-234. 
Imaizumi, Y. 1974. Statistical analysis on anencephaly, spina bifida and congenital hydrocephaly in Japan. Jap. J. Human. Genet. 19: 115-135.

Imaizumi, Y. 1976. Distribution of the incidence of anencephaly in Japan. Soc. Biol. $23: 66-72$. Imaizumi, Y., Shinozaki, N. and Aoki, H. 1975. Inbreeding in Japan: Results of a nation-wide study. Jap. J. Human Genet. 20: 91-107.

McKusick, V. A. 1975. Mendelian Inheritance in Man. The Johns Hopkins University Press, Baltimore and London, pp. 837.

Penrose, L. S. 1957. Genetics of anencephaly. J. Ment. Defic. Res. 1: 4-15.

Stevenson, A. C., Johnston, H. A., Stewart, M. I. P. and Golding, D. R. (eds.) 1966. Malformations of structures developed from the neural tube (B1-B7). In Congenital Malformations, Chap. 4, Bull. World Health Org., 34 (Suppl.). 